\title{
Metal Foam Analysis Based on CT Layers
}

\author{
Tamás Antal VARGA, ${ }^{1}$ Tamás MANKOVITS ${ }^{2}$ \\ University of Debrecen, Faculty of Engineering, Department of Mechanical Engineering, Debrecen, Hungary \\ ${ }^{1}$ varga.tamas@eng.unideb.hu \\ ${ }^{2}$ tamas.mankovits@eng.unideb.hu
}

\begin{abstract}
The geometrical modelling of metal foams remains one of the greatest challenges facing researchers in the field. In this paper the analysis of the inner structure of closed-cell aluminium foam - an essential part of the construction of an idealized foam model - is presented. With the application of special purpose software the properties of the foam cells can be mapped precisely and the results applied to the development of idealized foam geometry constructed in CAD applications.
\end{abstract}

Keywords: metal foam, CT, analysis, structure.

\section{Introduction}

Metal foams are relatively new and advanced materials with high stiffness to weight ratio, good thermal conductivity, good acoustic insulation and excellent energy absorption capability. This makes them ideal materials for a wide variety of applications [1-4]. Therefore, they have been increasingly employed in applications such as structural elements, automotive parts, sound and vibration absorbers and even biomedical implants [5-8], Basically, the mechanical properties of metal foams are influenced by three dominant factors [9-13]. the properties of the solid phase, the relative density of the solid phase and the spatial arrangement of the cells, that is, the structure of the metal foam (cell distribution, cell shape). The understanding of the structure - property correlations in metal foams is required for optimizing its mechanical performance for a given application [9-14].

\section{Analysis of metal foam structure based on computer tomography}

With the help of computer tomography several analytic tests can be carried out with suitably dedicated software, allowing the attributes of the cells constituting the metal foam to be mapped. The metal foam investigated is a closed cell alu- minium foam, which can be seen in Figure 1. The size of the 3D sample model is $14 \times 14 \times 14 \mathrm{~mm}^{3}$.

The shots made by the CT are imported into the dedicated software. The accuracy of the tests only relies on the accuracy of the CT device. The following attributes provide useful information regarding the metal foam's inner structure: the position of the cells (the $\mathrm{X}, \mathrm{Y}$ and $\mathrm{Z}$ coordinates of the centre of gravity), the size of the cells (the cell's volume and surface), and the form of the cells (how spheroidal the cell is). The software can determine these data thereby allowing us to identify the internal structure of the metal foam; moreover, these are the input data of the idealized 3D models.

The software is capable of visual display; hence more detail can be analysed including the segments of cells. After the performed analysis, we acquired the quantified data of cells and could also observe them visually as shown in Figure 2. During the analysis, the software detected 686 cells based on the parameters that we provided.

In Figure 2 we can see that the software falsely detected some cells outside of the perimeters of the 3D sample. This happened due to the fact that the 3D sample's outer surface is not homogenous; hence the software detected the open cells on the surface to which it assigned volume. These falsely detected cells can be detected with filtering, since the volume of these cells is much greater than the 
real cells constructing the metal foam. The basis of filtering could also be the centre of gravity of those cells outside the 3D sample, allowing them to be easily removed from the results of the analysis.

After filtering, the falsely detected cells became inactive leaving only the real cells in the model. 25 cells were removed thanks to the filter, hence in our main analysis 661 cells were examined. From the data acquired, it is possible to measure the dispersion of the cells' volume by size (Figure 3), and the dispersion of the spheroidicity (Figure 4) of the cells. It is shown by the dispersion of the cells' volume that nearly $60 \%$ have a volume of $0-2 \mathrm{~mm}^{3}$, while there are specifically large volume cells as well. The spheroidicity of cells varies from $0-1$, in which 1 represents the sphere attribute. From the analysis of the metal foam's inner structure it was shown that the cells are rather ellipsoid or general in shape, which raises further questions regarding the planning of the idealized model.

However, Figure 4 clearly shows that the cells have nearly the same spheroid attribute.

\section{Conclusions}

Our research has shown that CT shots of the given geometry are a necessary element of the analysis and modelling of metal foams. With the structure-analysing software we have the possibility to detect the place, size and form of the cells constituting the metal foam. We also have the opportunity to model even more phased metal
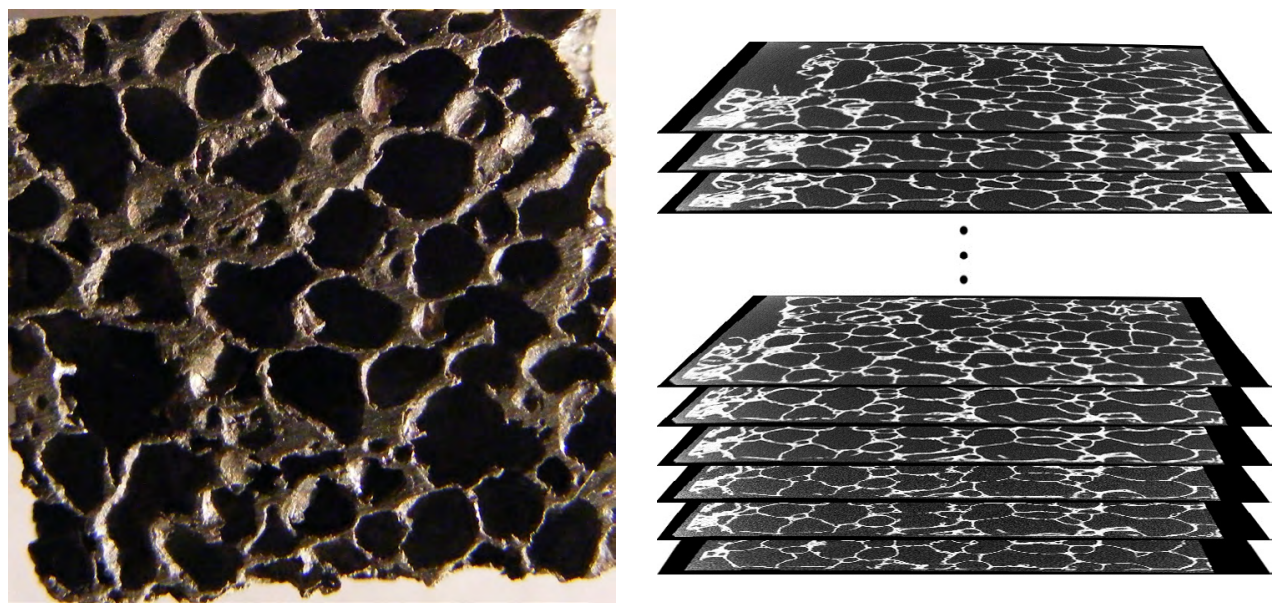

Figure 1. Closed cell aluminium foam $3 D$ sample model and the shots made by the CT
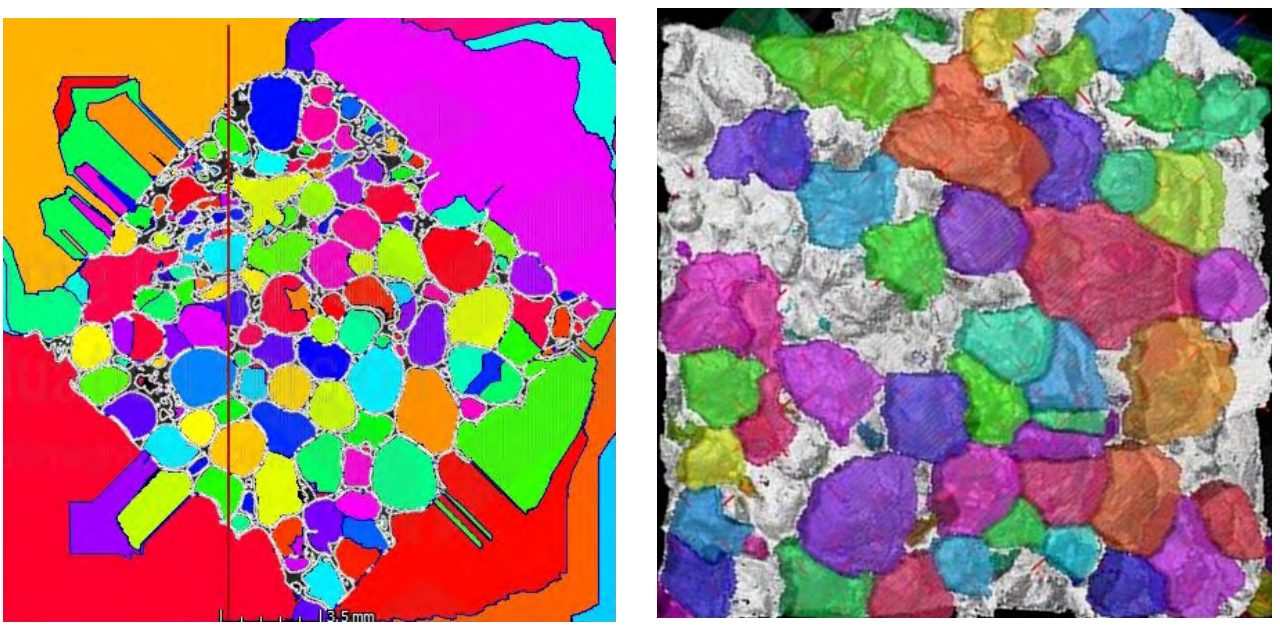

Figure 2. Cells detected before and after filtering 
foams, in terms of real geometry. Most probably this is the best process available for analysing our metal foam, its only disadvantage being the need for a CT device and (due to the fact that these processes demand high computing capacity) a high performance modelling computer.

\section{Acknowledgements}

This research was supported by the ÚNKP-4 New National Excellence Program of the Ministry of Human Capacities of Hungary.

\section{References}

[1] Ashby M. F., Evans A. G., Fleck N. A., Gibson L. J., Hutchinson J. W., Wadley H. N. G.: Metal foams. A design guide. Butterworth-Heinemann, 2000.

[2] Mankovits T., Budai I., Balogh G., Gábora A., Kozma I., Varga T., Manó S., Kocsis I.: Structural analysis and its statistical evaluation of a closed-cell metal foam. International Review Applied Science Engineering, 5/2. (2014) 135-143. https://doi.org/10.1556/IRASE.5.2014.2.5

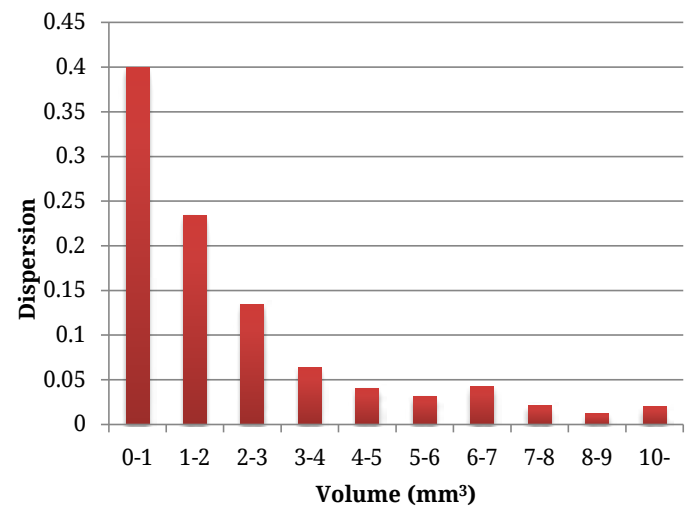

Figure 3. The dispersion of cell volume

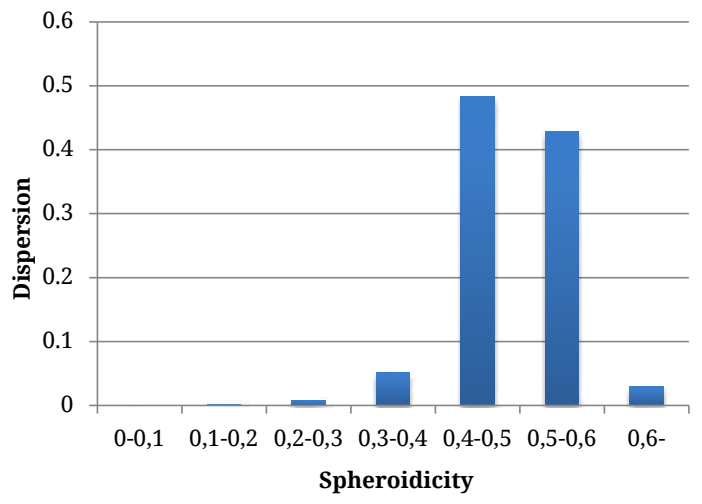

Figure 4. The dispersion of the spheroidicity of cells
[3] Orbulov I. N.: Compressive properties of aluminium matrix syntactic foams. Materials Science and Engineering A, 555. (2012) 52-56.

https://doi.org/10.1016/j.msea.2012.06.032

[4] Orbulov I. N., Májlinger K.: Description of the compressive response of metal matrix syntactic foams. Materials and Design, 49. (2013) 1-9. https://doi.org/10.1016/j.matdes.2013.02.007

[5] Kou D. P., Li J. R., Yu J. L., Cheng H. F.: Mechanical behavior of open-cell metallic foams with dual-size cellular structure. Scripta Materialia, 59/5. (2001) 483-486. https://doi.org/10.1016/j.scriptamat.2008.04.022

[6] Jang W. Y., Kyriakides S., Kraynik A. M.: On the compressive strength of open-cell metal foams with Kelvin and random cell structures. International Journal of Solids and Structures, 47/21. (2010) 2872-2883.

https://doi.org/10.1016/j.ijsolstr.2010.06.014

[7] Lu Z.-X., Liu Q., Huang J.-X.: Analysis of defects on the compressive behaviors of open-cell metal foams through models using the FEM. Materials Science and Engineering A, 530. (2011) 285-296. https://doi.org/10.1016/j.msea.2011.09.088

[8] An Y., Wen C., Hodgson P. D., Yang C.: Investigation of cell shape effect on the mechanical behaviour of open-cell metal foams. Computational Materials Science, 55. (2012) 1-9.

https://doi.org/10.1016/j.commatsci.2011.11.030

[9] Maire E., Fazekas A., Salvo L., Dendievel R., Youssef S., Cloetens P., Letang J. M.: X-ray tomography applied to the characterization of cellular materials. Related finite element modeling problems. Composites Science and Technology, 63. (2003) 2431-2443.

https://doi.org/10.1016/S0266-3538(03)00276-8

[10] Jirousek O., Doktor T., Kytyr D., Zlámal P., Fíla T., Koudelka P., Jandejsek I., Vavrík D.: $X$-ray and finite element analysis of deformation response of closed-cell metal foam subjected to compressive loading. Journal of Instrumentation, 8/2. (2013). https://doi.org/10.1088/1748-0221/8/02/C02012

[11] Youssef S., Maire E., Gaertner R.: Finite element modelling of the actual structure of cellular materials determined by $X$-ray tomography. Acta Materialia, 53/3. (2005) 719-730. https://doi.org/10.1016/j.actamat.2004.10.024

[12] Veyhl C., Belova I. V., Murch G. E., Fiedler T.: Finite element analysis of the mechanical properties of cellular aluminium based on microcomputed tomography. Materials Science and Engineering A, 528. (2011) 4550-4555. https://doi.org/10.1016/j.msea.2011.02.031

[13] Jeon I., Asahina T., Kang K.-J., Im S., Lu T. J.: Finite element simulation of the plastic collapse of closed-cell aluminum foams with X-ray computed tomography. Mechanics of Materials, 42. (2010) 227-236.

https://doi.org/10.1016/j.mechmat.2010.01.003 
[14] Mankovits T., Varga T. A., Manó S., Kocsis I.: Compressive response determination of closed-cell aluminium foam and linear-elastic finite element simulation of $\mu C T$-based directly reconstructed geometrical models. Strojniški vestnik. Journal of Mechanical Engineering, 64/2. (2018) 105-113.

https://doi.org/10.5545/sv-jme.2017.5048 